\title{
The changing culture of the microbiology laboratory
}

\author{
Kevin B Laupland MD MSc FRCPC ${ }^{1,2}$, Louis Valiquette MD MSc FRCPC 3
}

\begin{abstract}
$\mathrm{T}$ he development and implementation of novel diagnostic techniques has had a profound effect on microbiology laboratory services in recent decades. Traditional microscopy, culture and biochemical testing techniques have been the mainstay for identification and antimicrobial susceptibility testing of microorganisms for generations $(1,2)$. While these tests remain the core basis and standard practice in most laboratories, new techniques, such as nucleic acid-based assays and mass spectrometry, are increasingly being used. In some cases, these are enhancing existing diagnostic algorithms and, in others, they are replacing traditional testing approaches. Although these new techniques are powerful and offer many potential advantages over traditional methods, they have a number of limitations. In the present note, we briefly review new and evolving testing modalities in the microbiology laboratory. It is important to note that we did not intend to provide an in-depth technical appraisal of testing modalities. Rather, our objective was to highlight a number of new testing modalities in the context of traditional testing for bedside clinicians.
\end{abstract}

\section{THE TRADITIONAL MICROBIOLOGY LABORATORY}

Traditional or conventional microbiology testing has generally included microscopy, antigen detection, serology and culture. The use of microscopic assessment of direct clinical specimens dates back to the advent of microbiology and has had an important role in rapid detection of bacterial, fungal and protozoal diseases $(1,2)$. While in many cases it may represent a 'gold standard' for diagnosis, such as with malaria or stool parasites, in most cases, microscopy only offers a presumptive diagnosis that requires further confirmation with other testing modalities. In the case of viruses, electron microscopy is required but this is rarely practical for clinical purposes. Antigen detection techniques usually use monoclonal antibodies directed against specific antigens, and modalities include ELISA and tagged immune-microscopy. While these tests are usually quite specific and positivity indicates a diagnosis, their sensitivity is often low and a negative result is frequently clinically unhelpful. Serology testing is based on the detection of a host humoral response to infection. In some cases, this is very specific (such as with HIV infection with confirmatory Western blot) while in others, cross reactivity and nonspecific antibodies result in high rates of false positivity. Perhaps most importantly, time is needed for host serocoversion to the infecting agent such that they are rarely helpful in acute disease diagnosis and often only helpful in retrospect.

The principal means of conventional testing is culture. In the case of bacteria and fungi, clinical specimens are inoculated on a range of media and incubated. Use of selective and differential media may allow enhanced identification and suggest a presumptive diagnosis. In most cases, biochemical testing is then performed to identify species, and plating or broth dilution is used to determine antimicrobial susceptibilities. Generally speaking, when cultures are positive they represent a 'gold standard' diagnosis. However, occasionally, phenotypic testing alone presents a challenging diagnosis to species level. A greater problem arises with culturing due to its poor sensitivity. For example, blood cultures may only be positive in $10 \%$ to $15 \%$ of cases of severe pneumonia, and this is even lower in the presence of previous antimicrobial therapy. Furthermore, relying on incubation means that days are typically required for results for bacteria and yeast, and frequently weeks or months for fungi and mycobacteria. In severe disease, even hourly delays in treatment may have significant adverse effects on outcome (3). Antimicrobial susceptibility is generally highly predictive of clinical efficacy, although inducible enzymes can be misleading and failure can occur despite initial in vitro susceptibility. Culture of viruses and protozoa is fraught with difficulty and rarely useful in the clinical microbiology laboratory.

\section{MONOPLEX NUCLEIC ACID-BASED ASSAYS}

Nucleic acid-based tests are those that detect the DNA or RNA from a microorganism. A variety of commercially available nucleic acidbased tests have been developed and implemented into routine usage in many laboratories worldwide (4). Many laboratories also have 'inhouse' developed tests. In-house developed tests have the potential advantages of lower cost and may allow testing of agents for which there are no commercially available options. However, the degree of standardization and validation will be centre dependent.

Nucleic acid-based assays frequently use the principles (or modifications thereof) of the polymerase chain reaction (PCR), in which specific DNA primers are used along with DNA polymerase and substrate in heating-cooling cycles to amplify the target DNA (5). Detection of the PCR product may be through a number of modalities. In real-time PCR, the PCR reaction is monitored during the reactions such that the final product can be detected and also the amount of DNA in the original sample can be quantified $(6,7)$. RNA targets can also be amplified in a similar manner but usually require the use of reverse transcriptase to convert the RNA into complementary DNA. There are a number of differing modalities and techniques that have been used for nucleic acid-based tests in clinical microbiology laboratories, as exemplified in Table 1.

\section{MULTIPLEX ASSAYS}

In some clinical situations, testing for the presence or absence of a specific organism (eg, methicillin-resistant Staphylococcus aureus, gonorrhea, tuberculosis) is sought. However, in many others (eg, sepsis syndrome) testing a range of potential organisms may be desired. Traditionally, nucleic acid-based tests were developed to detect a single agent. New and evolving technologies are increasingly allowing testing of a wide range of pathogens within a single test.

In multiplex real-time PCR, multiple primers with differing associated detection markers are used such that multiple nucleic acid targets can be assayed simultaneously in a single tube. There have been extensive reports of in-house developed and commercially available multiplex real-time PCR tests applied to diagnosis of a wide range of bacterial, fungal, viral and protozoal diseases in recent years (18-22). Commercially available multiplex PCR tests that detect a wide range of pathogens have been developed for infectious syndromes including sepsis (23-25) and respiratory tract infections (26-29). Nucleic acidbased multiplex tests are superior to conventional testing for detection of respiratory pathogens where viruses are prevalent. However,

${ }^{1}$ Department of Medicine, Royal Inland Hospital, Kamloops, British Columbia; ${ }^{2}$ Departments of Medicine, Critical Care Medicine, Pathology and Laboratory Medicine and Community Health Sciences, University of Calgary, Calgary, Alberta; ${ }^{3}$ Department of Microbiology-Infectious

Diseases, Université de Sherbrooke, Sherbrooke, Quebec

Correspondence: Dr Kevin B Laupland, Royal Inland Hospital, 311 Columbia Street, Kamloops, British Columbia V2C 2T1.

Telephone 250-374-5111, e-mail klaupland@gmail.com 
TABLE 1

Examples of nucleic acid-based tests in the clinical microbiology laboratory

\begin{tabular}{|c|c|c|c|c|}
\hline Test modality & Description & Comments & Common examples & $\begin{array}{l}\text { Selected } \\
\text { references }\end{array}$ \\
\hline $\begin{array}{l}\text { Polymerase chain } \\
\text { reaction }\end{array}$ & $\begin{array}{l}\text { DNA amplified by thermocycling with heat stable } \\
\text { DNA polymerase }\end{array}$ & $\begin{array}{l}\text { Broad applicability and highly } \\
\text { amenable to in-house test } \\
\text { development; heat cycling } \\
\text { required }\end{array}$ & $\begin{array}{r}\text { Broad range of viruses, } \\
\text { bacteria and protozoa }\end{array}$ & $5,6,8,9$ \\
\hline Ligase chain reaction & $\begin{array}{l}\text { Four DNA primers with sequence gap ligated by DNA } \\
\text { ligase in setting of target DNA }\end{array}$ & Highly specific; sensitivity limited & Not widely currently used & 7 \\
\hline $\begin{array}{l}\text { Nucleic acid } \\
\text { sequence-based } \\
\text { amplification }\end{array}$ & $\begin{array}{l}\text { RNA amplified isothermally through complementary } \\
\text { double stranded DNA intermediate; reverse } \\
\text { transcriptase, RNAse } \mathrm{H} \text {, and T7 polymerase }\end{array}$ & Highly sensitive & $\begin{array}{l}\text { Hepatits C virus, HIV, } \\
\text { cytomegalvirus, } \\
\text { enteroviruses, methicillin- } \\
\text { resistant Staphylococcus } \\
\text { aureus }\end{array}$ & 10,11 \\
\hline $\begin{array}{l}\text { Transcription- } \\
\text { mediated } \\
\text { amplification }\end{array}$ & $\begin{array}{l}\text { RNA amplified isothermally through complementary } \\
\text { double-stranded DNA intermediate; reverse } \\
\text { transcriptase, RNA polymerase }\end{array}$ & Highly sensitive & $\begin{array}{l}\text { Mycobacteria, Neisseria, } \\
\text { chlamydia }\end{array}$ & 12 \\
\hline Branched DNA & $\begin{array}{l}\text { Signal amplification by branched enzyme conjugated } \\
\text { hybridization probes }\end{array}$ & $\begin{array}{l}\text { Signal amplification but not nucleic } \\
\text { acid amplification; technically } \\
\text { simple; quantitative }\end{array}$ & HIV, hepatitis $B$, hepatitis $C$ & 13 \\
\hline $\begin{array}{l}\text { Strand displacement } \\
\text { amplification }\end{array}$ & $\begin{array}{l}\text { Two sets of primers, exonuclease deficient, DNA } \\
\text { polymerase, and restriction nuclease used to generate a } \\
\text { hemiphosphorinated DNA hybrid; restriction enzyme nick } \\
\text { promotes DNA systhesis as DNA polymerase repairs }\end{array}$ & $\begin{array}{l}\text { Highly specific and sensitive. } \\
\text { Limited to DNA }\end{array}$ & $\begin{array}{l}\text { Mycobacteria, chlamydia, } \\
\text { gonorrhea, herpes simplex } \\
\text { virus }\end{array}$ & $14-16$ \\
\hline Hybrid capture & $\begin{array}{l}\text { RNA probes hybridized to DNA target, antibody capture } \\
\text { and signal amplification }\end{array}$ & & Human papillomavirus & 17 \\
\hline
\end{tabular}

although results are available in a fraction of the time, this is not necessarily the case for bacterial and fungal diseases. For example, in the most studied of these for sepsis, the LightCycler SeptiFast (Roche Diagnostics, Germany) multiplex PCR, which tests for 25 common pathogens from blood samples, has been found in a recent review to have an approximate overall sensitivity of $75 \%$ and specificity of $92 \%$ for bacteremia/fungemia, with better performance in general for bacterial pathogens (23).

A potential limitation of multiplex PCR is that as the number of pathogens tested increases, the possibility for interactions or crossreactivity increases. Microarrays and microbead technologies have been developed to further facilitate simultaneous testing of a broad range of pathogens with a high degree of sensitivity and specificity within a single assay. Microarrays enable the testing of multiple individual monoplex assays within a single microtesting card. Microarrays have been developed for panel testing of positive blood cultures, enteropathogens, and a wide range of $\beta$-lactamase resistance genes with high sensitivity and specificity (30-33). Luminex (Luminex Molecular Diagnostics, USA) multiplex bead-based technology has evolved from flow-cytometry and has been successfully applied to both immune assays and nucleic acid-based tests (34). In this technology, microscopic colour-coded beads (microspheres) are linked to a reagent that is then assayed with a light source that analyzes each reagent with a paired reporter dye. DNA-tagged tests can include up to 100 analytes within a single sample. This technology has been successfully demonstrated to be highly efficient and to accurately identify a range of pathogens including those from stool and the respiratory tract $(35,36)$.

\section{SEQUENCE-BASED TESTING}

DNA sequencing has undergone major advances in recent decades. While previously a labourious, slow and expensive process limited only to large research laboratories, technological advancements and automation have made sequencing significantly more affordable and efficient, and has allowed its implementation into smaller reference and mid-to-large clinical microbiology laboratories. While phenotypic identification, including morphological and biochemical characterization, has traditionally been the standard for the speciation of microorganisms, this has now been replaced by sequencing.
In bacteria and fungi, sequence-based identification of $16 \mathrm{~S}$ and $18 \mathrm{~S}$ ribosomal RNA genes, respectively, has become the standard for classification. The general process involves isolation of microorganisms using standard techniques, amplification by PCR, purification of the product and then sequencing. Ribosomal RNA genes are used as the primary targets because they are highly conserved among species and, thus, enable accurate identification (37). Universal primers that are complementary to the highly conserved regions across all bacteria are used. The resulting sequence is then compared with reference databanks to identify the organism. While widely regarded as the 'gold standard' test for organism identification, a number of considerations, most importantly its relatively high cost, precludes its routine use in the clinical microbiology laboratory (38). Several studies have documented its value as a complementary test to conventional culture in challenging-to-diagnose infections $(39,40)$. Unlike with bacteria and fungi, for which conventional phenotypic testing remains the standard for assessment of antimicrobial resistance, sequence-based testing of viruses has become the standard means of evaluation for antiviral resistance.

\section{MASS SPECTROMETRY}

The most recent and important development in the clinical microbiology laboratory has been advances in mass spectrometry technology and its application to biomolecules (41). Traditional mass spectrometry uses thermal vaporization to convert and separate molecules into gas phase ions for spectrometry. However, because of degradation, this approach is not suitable for large biomolecules. In response, matrixassisted laser desorption ionization time-of-flight (MALDI-TOF) has been developed (42). In MALDI-TOF, samples are embedded in a small organic compound crystalline structure of small organic compound matrix and are then deposited on a conductive sample support for ultraviolet laser desorption for spectrometric analysis. By using this approach, analysis of biomolecules, such as DNA, peptides and proteins, is possible.

In the clinical microbiology laboratory setting, bacterial or fungal colonies are subjected to MALDI-TOF analysis and the resulting spectrum is then compared (12) with spectra from reference databases. The MALDI-TOF procedure requires minimal sample preparation, 
is analyzed very quickly and an identification result to the genera or species level is typically available within minutes of sample application. The resulting identification is highly accurate and generally comparable with automatic biochemical testing (43). This is also the case for mycobacteria (44). In many cases, identification among species or even strains within genera is possible (45). However, in some other cases, it may not differentiate closely related organisms such as between Escherichia coli and Shigella species, and among different viridans group streptococci (41). Importantly, the output from a MALDITOF analysis includes an estimate of the probability of a match such that a level of confidence is available with the determination. It is important to recognize that the ability of MALDI-TOF to correctly identify isolates is, in part, predicated on the quality of the reference spectra database. Earlier studies and those with fewer isolates included in the reference spectra have been less accurate $(43,46)$.

While the value of MALDI-TOF for organism identification is readily apparent, there is now increasing evidence that this technique may be further applied in other areas (47). While a recent and evolving area, several investigators have used MALDI-TOF to rapidly and accurately identify organisms with a range of $\beta$-lactamases, identify vancomycin-resistant enterococci, and differentiate between methicillinsensitive and methicillin-resistant $S$ aureus (47). There is also great promise for developing this technique for the detection and subtyping of viruses (48).

\section{REFERENCES}

1. Austrian R. The Gram stain and the etiology of lobar pneumonia, an historical note. Bacteriol Rev 1960;24:261-5.

2. Gram HC. Über die isolierte Färbung der Schizomyceten in Schnittund Trockenpräparaten. Fortschritte der Medizin. 1884;2:185-9.

3. Kumar A, Roberts D, Wood KE, et al. Duration of hypotension before initiation of effective antimicrobial therapy is the critical determinant of survival in human septic shock. Crit Care Med 2006;34:1589-96

4. Lawn SD, Mwaba P, Bates M, et al. Advances in tuberculosis diagnostics: The Xpert MTB/RIF assay and future prospects for a point-of-care test. Lancet Infect Dis 2013;13:349-61.

5. Mullis KB, Faloona FA. Specific synthesis of DNA in vitro via a polymerase-catalyzed chain reaction. Methods Enzymol 1987; 155:335-50.

6. Yu AC, Vatcher G, Yue X, et al. Nucleic acid-based diagnostics for infectious diseases in public health affairs. Front Med 2012;6:173-86.

7. Monis PT, Giglio S. Nucleic acid amplification-based techniques for pathogen detection and identification. Infect Genet Evol 2006;6:2-12.

8. Antonenka U, Hofmann-Thiel S, Turaev L, et al. Comparison of Xpert MTB/RIF with ProbeTec ET DTB and COBAS TaqMan MTB for direct detection of M. tuberculosis complex in respiratory specimens. BMC Infect Dis 2013;13:280.

9. Banada PP, Chakravorty S, Shah D, Burday M, Mazzella FM, Alland D. Highly sensitive detection of Staphylococcus aureus directly from patient blood. PLoS One 2012;7:e31126.

10. Compton J. Nucleic acid sequence-based amplification. Nature 1991;350:91-2.

11. Chang CC, Chen CC, Wei SC, Lu HH, Liang YH, Lin CW. Diagnostic devices for isothermal nucleic acid amplification. Sensors (Basel) 2012;12:8319-37.

12. Chernesky MA, Jang DE. APTIMA transcription-mediated amplification assays for Chlamydia trachomatis and Neisseria gonorrhoeae. Expert Rev Mol Diagn 2006;6:519-25.

13. Pachl C, Todd JA, Kern DG, et al. Rapid and precise quantification of HIV-1 RNA in plasma using a branched DNA signal amplification assay. J Acquir Immune Defic Syndr Hum Retrovirol 1995;8:446-54.

14. Van Der Pol B, Warren T, Taylor SN, et al. Type-specific identification of anogenital herpes simplex virus infections by use of a commercially available nucleic acid amplification test. J Clin Microbiol 2012;50:3466-71.

15. Killick V, Kell P, Plumb H, Hurd N, Turner P. Screening for Neisseria gonorrhoeae using the BD ProbeTec nucleic acid amplification test in a low prevalence genitourinary medicine clinic. Int J STD AIDS 2012;23:e1-3.
There are at least two major manufacturers of MALDI-TOF instruments, and these are progressively becoming implemented in clinical laboratories. For example, approximately one-half of hospital laboratories in France now use this technology (49). While having high initial acquisition costs for the machine, MALDI-TOF has the benefit that day-to-day consumables are of minimal cost and the need to refer strains to reference laboratories is markedly reduced.

\section{CONCLUSION}

The recent decades have witnessed a major change in the clinical microbiology laboratory. The development of nucleic acid-based tests has revolutionized clinical virology; virus culture and serology has largely become obsolete. Although selected nucleic acid-based tests have replaced a number of traditional bacteriology tests, by and large, the vast majority of these provide complementary information to traditional culture-based tests. Multiplex nucleic acid-based tests and arrays and MALDI-TOF technologies and applications are rapidly evolving and will inevitably have a significant effect on our ability to offer prompt and effective antimicrobial therapy to our patients. However, similar to conventional laboratory techniques, it is imperative that the bedside clinician be aware of the benefits and limitations of these new tests to provide safe and optimal patient care.
16. Walker GT, Fraiser MS, Schram JL, Little MC, Nadeau JG, Malinowski DP. Strand displacement amplification - an isothermal, in vitro DNA amplification technique. Nucleic Acids Res 1992;20:1691-6.

17. Gillio-Tos A, De Marco L, Carozzi FM, et al. Clinical impact of the analytical specificity of Hybrid Capture 2: Data from the NTCC study. J Clin Microbiol 2013.

18. Hazelton BJ, Thomas LC, Unver T, Iredell JR. Rapid identification of Gram-positive pathogens and their resistance genes from positive blood culture broth using a multiplex tandem RT-PCR assay. J Med Microbiol 2013;62:223-31.

19. Elbir H, Henry M, Diatta G, et al. Multiplex real-time PCR diagnostic of relapsing fevers in Africa. PLoS Negl Trop Dis 2013;7:e2042.

20. Kim H, Jeong SH, Kim M, Lee Y, Lee K. Detection of Clostridium difficile toxin A/B genes by multiplex real-time PCR for the diagnosis of C. difficile infection. J Med Microbiol 2012;61:274-7.

21. Njouom R, Yekwa EL, Cappy P, Vabret A, Boisier P, Rousset D. Viral etiology of influenza-like illnesses in Cameroon, JanuaryDecember 2009. J Infect Dis 2012;20(6 Suppl 1):S29-35.

22. Park Y, Kim BS, Choi KH, et al. A novel multiplex real-time PCR assay for the concurrent detection of hepatitis $A, B$ and $C$ viruses in patients with acute hepatitis. PLoS One 2012;7:e49106.

23. Chang SS, Hsieh WH, Liu TS, et al. Multiplex PCR system for rapid detection of pathogens in patients with presumed sepsis - a systemic review and meta-analysis. PLoS One 2013;8:e62323.

24. Fitting C, Parlato M, Adib-Conquy M, et al. DNAemia detection by multiplex PCR and biomarkers for infection in systemic inflammatory response syndrome patients. PLoS One 2012;7:e38916.

25. Blaschke AJ, Heyrend C, Byington CL, et al. Rapid identification of pathogens from positive blood cultures by multiplex polymerase chain reaction using the FilmArray system. Diagn Microbiol Infect Dis 2012;74:349-55.

26. Perez-Ruiz M, Pedrosa-Corral I, Sanbonmatsu-Gamez S, Navarro-Mari M. Laboratory detection of respiratory viruses by automated techniques. Open Virol J 2012;6:151-9.

27. Van Wesenbeeck L, Meeuws H, Van Immerseel A, et al. Comparison of the Filmarray RP, the Verigene RV+ and the Prodesse ProFLU+/FAST+ multiplex platforms for detection of influenza viruses in clinical samples from the 2011-2012 influenza season in Belgium. J Clin Microbiol 2013. (In Press)

28. Pierce VM, Hodinka RL. Comparison of the GenMark Diagnostics eSensor respiratory viral panel to real-time PCR for detection of respiratory viruses in children. J Clin Microbiol 2012;50:3458-65.

29. Forman MS, Advani S, Newman C, Gaydos CA, Milstone AM, Valsamakis A. Diagnostic performance of two highly multiplexed respiratory virus assays in a pediatric cohort. J Clin Virol 2012;55:168-72. 
30. Liu J, Gratz J, Amour C, Kibiki G, et al. A laboratory-developed TaqMan Array Card for simultaneous detection of 19 enteropathogens. J Clin Microbiol 2013;51:472-80.

31. Cuzon G, Naas T, Bogaerts P, Glupczynski Y, Nordmann P. Evaluation of a DNA microarray for the rapid detection of extended-spectrum beta-lactamases (TEM, SHV and CTX-M), plasmid-mediated cephalosporinases (CMY-2-like, DHA, FOX, ACC-1, ACT/MIR and CMY-1-like/MOX) and carbapenemases (KPC, OXA-48, VIM, IMP and NDM). J Antimicrob Chemother 2012;67:1865-9.

32. Leinberger DM, Grimm V, Rubtsova M, et al. Integrated detection of extended-spectrum-beta-lactam resistance by DNA microarraybased genotyping of TEM, SHV, and CTX-M genes. J Clin Microbiol 2010;48:460-71.

33. Tissari P, Zumla A, Tarkka E, et al. Accurate and rapid identification of bacterial species from positive blood cultures with a DNA-based microarray platform: An observational study. Lancet 2010;375:224-30.

34. Shoma S, Verkaik NJ, de Vogel CP, et al. Development of a multiplexed bead-based immunoassay for the simultaneous detection of antibodies to 17 pneumococcal proteins. Eur J Clin Microbiol Infect Dis 2011;30:521-6.

35. Mengelle C, Mansuy JM, Prere MF, et al. Simultaneous detection of gastrointestinal pathogens with a multiplex Luminex-based molecular assay in stool samples from diarrhoeic patients. Clin Microbiol Infect 2013 (In Press).

36. Popowitch EB, O'Neill SS, Miller MB. Comparison of the Biofire FilmArray RP, Genmark eSensor RVP, Luminex xTAG RVPv1, and Luminex xTAG RVP fast multiplex assays for detection of respiratory viruses. J Clin Microbiol 2013;51:1528-33.

37. Clarridge JE III. Impact of $16 \mathrm{~S}$ rRNA gene sequence analysis for identification of bacteria on clinical microbiology and infectious diseases. Clin Microbiol Rev 2004;17:840-62.

38. Boudewijns M, Bakkers JM, Sturm PD, Melchers WJ. 16S rRNA gene sequencing and the routine clinical microbiology laboratory: A perfect marriage? J Clin Microbiol 2006;44:3469-70.

39. Haag H, Locher F, Nolte O. Molecular diagnosis of microbial aetiologies using SepsiTest in the daily routine of a diagnostic laboratory. Diagn Microbiol Infect Dis 2013 (E-pub June 12, 2013).
40. Kuhn C, Disque C, Muhl H, Orszag P, Stiesch M, Haverich A. Evaluation of commercial universal rRNA gene PCR plus sequencing tests for identification of bacteria and fungi associated with infectious endocarditis. J Clin Microbiol 2011;49:2919-23.

41. Patel R. Matrix-assisted laser desorption ionization-time of flight mass spectrometry in clinical microbiology. Clin Infect Dis 2013 (E-pub April 19, 2013).

42. Hillenkamp F, Karas M. Mass spectrometry of peptides and proteins by matrix-assisted ultraviolet laser desorption/ionization. Methods Enzymol 1990;193:280-95.

43. Clark AE, Kaleta EJ, Arora A, Wolk DM. Matrix-assisted laser desorption ionization-time of flight mass spectrometry: A fundamental shift in the routine practice of clinical microbiology. Clin Microbiol Rev 2013;26:547-603.

44. Balada-Llasat JM, Kamboj K, Pancholi P. Identification of Mycobacteria from solid and liquid media by matrix-assisted laser desorption/ionization time-of-flight mass spectrometry in the clinical laboratory. J Clin Microbiol 2013 (E-pub June 28, 2013).

45. Moon HW, Lee SH, Chung HS, Lee M, Lee K. Performance of the VITEK MS Matrix-Assisted Laser Desorption Ionization-Time of Flight Mass Spectrometry system for identification of Gram-positive cocci routinely isolated in clinical microbiology laboratories. J Med Microbiol 2013 (E-pub June 15, 2013).

46. Seng P, Drancourt M, Gouriet F, et al. Ongoing revolution in bacteriology: Routine identification of bacteria by matrix-assisted laser desorption ionization time-of-flight mass spectrometry. Clin Infect Dis 2009;49:543-51.

47. Hrabak J, Chudackova E, Walkova R. Matrix-assisted laser desorption ionization-time of flight (MALDI-TOF) mass spectrometry for detection of antibiotic resistance mechanisms: From research to routine diagnosis. Clin Microbiol Rev 2013;26:103-14.

48. Mengelle C, Mansuy JM, Da Silva I, Guerin JL, Izopet J. Evaluation of a polymerase chain reaction-electrospray ionization time-of-flight mass spectrometry for the detection and subtyping of influenza viruses in respiratory specimens. J Clin Virol 2013;57:222-6.

49. Inserm. MALDI-TOF déshabille toutes les bactéries. 2013 [cited 2013 July 24]; <www.inserm.fr/actualites/rubriques/actualites-recherche/ maldi-tof-deshabille-toutes-les-bacterie> (Accessed July, 24, 2013). 


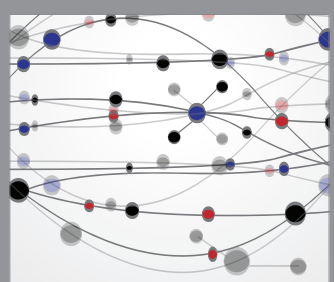

The Scientific World Journal


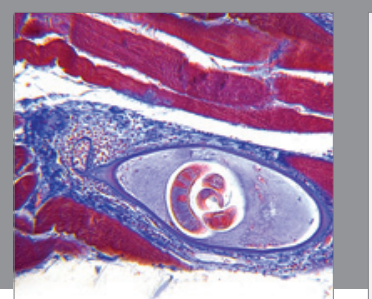

Gastroenterology Research and Practice

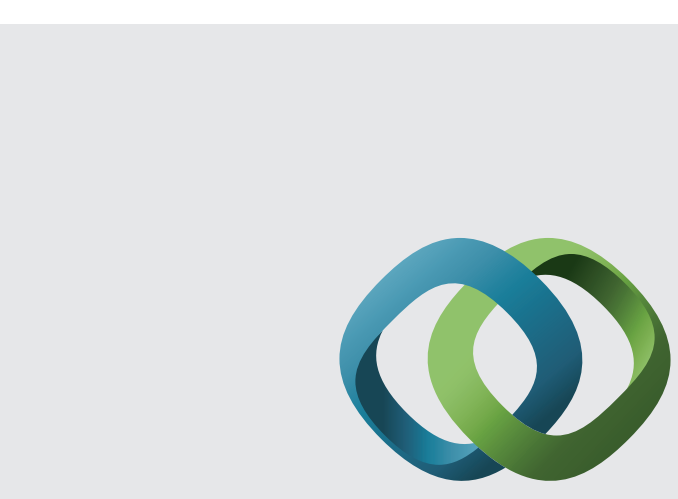

\section{Hindawi}

Submit your manuscripts at

http://www.hindawi.com
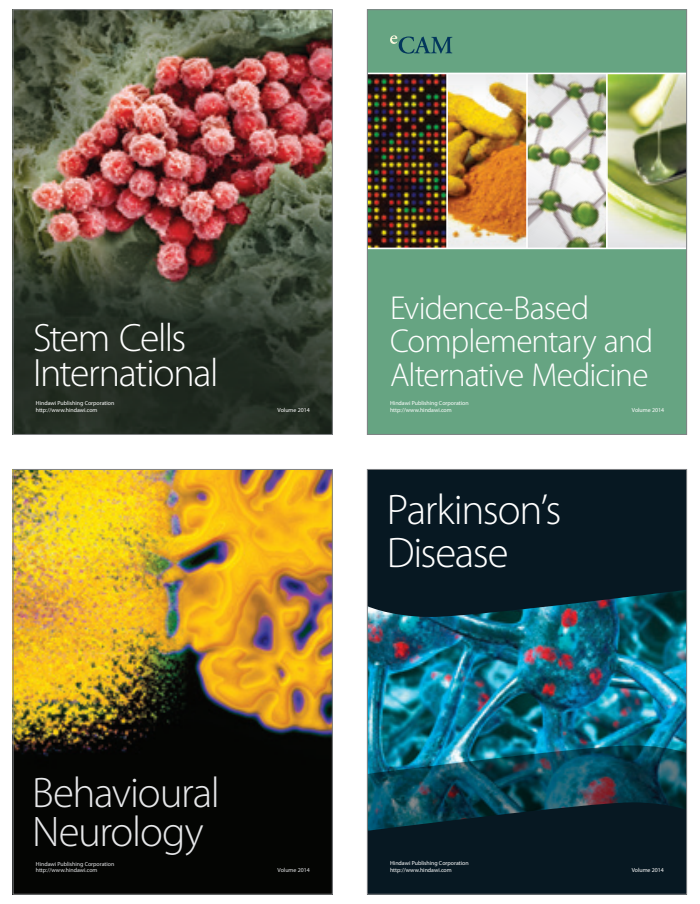
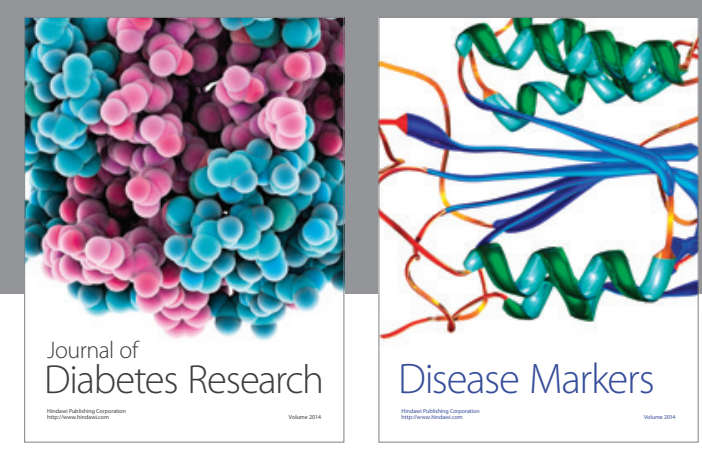

Disease Markers
